LIBRI

www.libridergi.org

Kitap Tanıtımı, Eleştiri ve Çeviri Dergisi

Journal of Book Notices, Reviews and Translations

Volume I (2015)

H. ÇAL, Boyovası/Boyabat Kazasında Türk Mimarisi (Hurufat Defterlerine Göre). Ankara 2014. Atatürk Kültür Merkezi Başkanlığı, 517 sayfa. ISBN: 9789751628527

\section{Lokman TAY}

Libri: Kitap Tanıtımı, Eleştiri ve Çeviri Dergisi'nde bulunan içeriklerin tümü kullanıcılara açık, serbestçe/ücretsiz 'açık erişimli' bir dergidir. Kullanıcılar, yayıncıdan ve yazar(lar)dan izin almaksızın, dergideki makaleleri tam metin olarak okuyabilir, indirebilir, dağıtabilir, makalelerin çıktısını alabilir ve kaynak göstererek makalelere bağlantı verebilir.

Libri, uluslararası hakemli elektronik (online) bir dergi olup değerlendirme süreci biten makaleler derginin web sitesinde (www.libridergi.org) yıl boyunca ilgili sayının içinde (Volume I: Ocak-Aralık 2015) yayımlanır. Aralık ayı sonunda ilgili yıla ait sayı tamamlanır.

Dergide yayımlanan eserlerin sorumluluğu yazarlarına aittir.

Künye H. ÇAL, Boyovası/Boyabat Kazasında Türk Mimarisi (Hurufat Defterlerine Göre). Ankara 2014. Atatürk Kültür Merkezi Başkanlığı, 517 sayfa. ISBN: 9789751628527. Tanıtan: Lokman TAY, Libri I (2015) 89-92. DOI: 10.20480/lbr.2015115471

Geliş Tarihi: 12.11 .2015

Kabul Tarihi: 16.11.2015

Online Yayın Tarihi: 29.12.2015

URL: http://dx.doi.org/10.20480/lbr.2018115471

Editörya Phaselis Project

www.phaselis.org 


\section{H. ÇAL, Boyovası/Boyabat Kazasında Türk Mimarisi (Hurufat Defterlerine Göre). Ankara 2014. Atatürk Kültür Merkezi Başkanlığı, 517 sayfa. ISBN: 9789751628527}

Adından da anlaşılacağa üzere kitap, hurufat defterleri esas alınarak hazırlanmış bir çalışmadır. Bu sebeple öncelikle hurufat defterlerinin ne olduğundan kısaca bahsedip daha sonra kitabın incelenmesine geçebiliriz. Hurufat Defterleri: mütevelli, zaviyedar, türbedar, imam, müezzin vb. gibi cami, tekke ve türbe gibi vakıf yapılarında çalışan görevlilerin tayinlerinin kaydedildiği defterlerdir. Verdiği bu bilgilerden ötürü Hurufat Defterleri, başta tarih olmak üzere, mimarlık tarihi, sanat tarihi, iktisat tarihi ve halkbilimi gibi birçok bilim dalının ortak araştırma alanını oluşturmaktadır. Bu sebeple, Hurufat Defterleri ile ilgili çalışmalar, farklı disiplinlerden araştırmacıların bir arada yürütmesi gereken araştırmalardandır. Hurufat Defterlerindeki bilgilerden tam anlamıyla faydalanılabilmesi için bu gereklidir. Sanat tarihi araştırmalarında Hurufat Defterleri sınırlı sayıda araştırmacı dışında bugüne kadar genellikle göz ardı edilmiştir. Bu konudaki çalışmalar sanat tarihi adına son yıllarda biraz daha ön plana çıkmaya başlamıştır. Değerli hocamız, bu alanda salt Hurufat Defterleri'nden hareketle yeni çalışmalar yapılabileceğini ortaya koymuştur.

Kitap, Giriş (1-12), Hurufat Defterlerindeki Kayıtlarda Boyabat Kazasında Adı Geçen Köyler ve Yapılar (13-383), Kayıtlarımız Dışında Başka Arşiv Belgelerinde Adı Geçen Köyler (384-388), Kayıtlarımız Dışında Diğer Arşiv Belgelerinde Adı Geçen Yapılar (389-394), Sonuç (395-397), Yararlanılan Kaynaklar (398-417) ve Ekler (417-517) olmak üzere yedi bölümden oluşmaktadır.

Dört ayrı başlık altında ele alınan Giriş (1-12) bölümünde konunun sınırları ve önemi, yöntem ve tarihçeyle birlikte yararlanılan kaynaklar hakkında bilgi verilmektedir. Konunun sınırlarını, Vakıflar Genel Müdürlüğü Arşivi'nden temin edilen hurufat defterlerine göre Osmanlı dönemi Boyabat kazasındaki (günümüzde Sinop iline bağlı) Türk devri mimarisi oluşturmaktadır. Söz konusu defterlerin günümüz Türkçesine çevirileri yapılmış ve Boyabat kazası köyleri ile adı geçen yapıların listesi çıkarılarak arazi çalışması gerçekleştirilmiştir. Yerleri tespit edilebilen ve günümüze ulaşan yapılar bizzat yerinde görülüp fotoğraf ve çizimle belgelenerek ayrıntılı mimari tanımları yapıımıştır. Günümüze ulaşamayan veya köy adının değişmesi, yanlış yazılması, yapının yenilenmesi gibi sebeplerle ulaşılamayan yapılar ise defterlerde geçen bilgiler ve çeşitli arşiv belgelerinden hareketle tanııımaya çalışımıştır. En azından bugün varlığı bilinmeyen birçok yapının tespiti bu sayede gerçekleştirilmiştir. Tarihçe bölümünde bölgenin Hititlerden itibaren yerleşim yeri olarak kullanıldığı, birçok devletin de zaman içerisinde bu bölgede hüküm sürdüğü

\footnotetext{
*Yrd. Doç. Dr., Akdeniz Üniversitesi, Edebiyat Fakültesi, Sanat Tarihi Bölümü, Antalya. lokmantay@gmail.com.tr
} 
ifade edilmektedir. 1071 Malazgirt Savaşı'ndan sonra bölge, Müslüman Türklerin egemenliğine geçmiştir. Türk-i̇slam döneminde de çeşitli devletler ve beylikler bölgeye hâkim olmuşlardır. Son olarak Boyabat'la ilgili yapılmış az sayıdaki bilimsel çalışma da Giriş bölümünde kısaca tanıtılmaktadır.

Hurufat Defterlerindeki Kayıtlarda Boyabat Kazasında Adı Geçen Köyler ve Yapılar (13-383), başlıklı ikinci bölüm kitabın ana bölümünü oluşturmakta ve sekiz alt başlıktan meydana gelmektedir. Boyabat Kasabası́ndaki Yapılar (13-28) başlıklı ilk bölümünde yapılar, cami ve mescitler, dükkânlar, hamamlar, helâ, kale, mahkeme, musalla, okullar ve tekkeler olmak üzere yapı türlerine göre incelenmektedir. Mevcut yapılar plan, fotoğraf ve mimari tanımlarla belgelenmektedir. Yıkılmış veya herhangi bir sebeple ulaşılamamış yapılar ise arşiv belgelerinden hareketle tanıtılmaktadır. Kasaba merkezi yapı çeşitliliği bakımından oldukça zengin olmasına karşın defterlerden tespit edilen yapıların büyük çoğunluğunun yıkıldığı anlaşılmaktadır. Hurufat Defterlerinde Boyabat Nahiye ve Köylerindeki Yapılar (28-315) başlıklı ikinci bölümünde nahiye ve köylerdeki yapılar ele alınmaktadır. Bu bölümde köyler alfabetik olarak sıralanmakta ve defterlerde köylerle ilgili geçen bilgiler ve yapılar anlatılmaktadır. Kasaba merkezindeki yapılar için uygulanan yöntem burada da aynı şekilde geçerlidir. Giriş (1-12) bölümünde verilen bilgilerden Boyabat arazisinin çok engebeli ve dik olduğunu, köylere ulaşmanın da ne kadar zor olduğunu öğrenmekteyiz. Bütün bu zorluklara rağmen yapı olduğu tespit edilen bütün köylere gidilmiş ve arazi çalışması gerçekleştirilmiştir. Hurufat Defterlerindeki Kayıtlarda Yerleşim Yeri Yazılmayan Yapılar (315-318) başıklı üçüncü bölümde doğrudan yapı türü belirtilip nerede olduğu ifade edilmeyen yapılar ele alınmaktadır. Bu bölümdeki yapılar, camiler ve zaviyeler olmak üzere iki başlık altında toplanmaktadır. Hurufat Defterlerinde adı Geçen Fakat Yerini Bulamadığımız Köyler (318) başıklı bölümde defterlerde adı geçen ancak, adının yanlış yazııması, yanlış okunması, köylerin ikinci adının olması, köy adlarının değişmiş olması gibi sebeplerden ötürü bulunamayan köylerin isimleri verilmektedir. Yapı Vakıflarında Adı Geçen Köyler (318) başıkı bölümde Boyabat'taki yapıların vakıf kayıtlarında adı geçen 18 köy tespit edilmiştir. Bu köyler muhtemelen vakfı oldukları yapılara gelir getirmesi için akar tayin edilen köylerdir. Idari Yapı ve Köyler (318-322) başlıklı bölümde Hurufat Defterlerinde geçen idari birimler ele alınmıştır. Bu bağlamda defterlerden 282 adet köy adı tespit edilmiştir. Ancak bunlardan 108 adedinin yeri belirlenememiştir. Yukarıda ifade ettiğimiz gibi bunun da çeşitli sebepleri mevcuttur. Ancak tespit edilen köylerin yaklaşık 1/3'lük bir bölümünün bulunamayışı oldukça yüksek bir orandır. Diğer bir idari birim olan Divanların özellikle dağlık bölgelerdeki köylerin merkezi konumunda büyük yerleşim yerleri (köyle nahiye arasında) olduğu, ancak Boyabat'taki Divanların mahiyetinin tam olarak anlaşılamadığı ifade edilmektedir. Nahiye, Osmanlı döneminde bir kadılı̆ın bölgesi içinde olup kadının kendisinin gitmediği ancak yerine kendisine vekâleten kadılık yetkisini kullanacak bir naibi atadığı idari birimdir. Yapılan çalışma neticesinde Boyabat kazasına bağı on nahiye olduğu tespit edilmiştir. Ancak 1928 yılına gelindiğinde Boyabat kazasında merkezle birlikte iki nahiye kalmıştır. Diğer nahiyeler ise bu vasfını kaybetmiştir.

Hurufat Defterlerindeki Kayıtlarda Adı Geçen Yapılar ve Mimari Değerlendirme (323-373) başı।ılı bölümde öncelikle hurufat defterlerinden elde edilen verilerden sağlıklı bir liste çıkarmanın ne kadar zor olduğu üzerinde durulmaktadır. Burada aynı yapının farklı isimlerle yazılmış olması, zaman içerisinde yenilenmesi ve mescitlerin camiye çevrilmesi gibi sorunlar üzerinde durulmaktadır. Defterlerden 1681-1835 yılları arasında Boyabat'la ilgili 2270 kayıt 
incelenmektedir. Bu kayıtlarda 382 cami ve mescit, 1 çeşme, 1 değirmen, 6 dükkân, 4 hamam, 2 kale, 2 köprü, 1 kuyu, 1 medrese, 1 mahkeme, 2 musalla, 4 okul, 1 türbe, 1 tuvalet ve 63 zaviye olmak üzere 15 farklı yapı türünde toplam 469 bina adı geçmektedir. Tekrar edilenler çıktığında geriye 425 yapı kalmaktadır. Ancak yapılan arazi çalışmasında 97 cami ve mescit, 4 türbe ve 2 hamam olmak üzere toplam 103 yapı tespit edilmiştir. Ancak bu yapıların bir kısmı Osmanlı ve Cumhuriyet Dönemlerinde yenilenmişlerdir.

Sayısal olarak yapı dağılımına baktığımız zaman, cami ve mescitlerin fazla olması normaldir. Ancak zaviye sayısının bu kadar yüksek olması şaşırtıcıdır. Yazar, bölge güvenliğinin sağlanması adına devlet tarafından zaviyelerin desteklenmiş olabileceğini ileri sürmektedir. Zaviye sayısının bu kadar yüksek olmasına karşın kayıtlarda sadece bir tane türbe adının geçmesi, türbelerin zaviyelerin bir parçası olarak inşa edildiğini düşündürmektedir. Nitekim kayıtlarda geçmeyen dört türbenin arazi çalışmasında tespit edilmesi bunu göstermektedir.

Malzeme ve teknik olarak baktığımız zaman bölgenin ormanlık olmasından dolayı ahşap malzemenin ve buna bağlı olarak da çantı tekniğinin ön plana çıktığı görülmektedir. Yapıların 43 tanesi ahşaptan çantı tekniğinde, 1 tanesi ahşap karkas arası tuğla dolgu tekniğinde ve kalan 58 tanesi ise taş duvarlı ahşap tavanlı olarak yapılmışlardır. Plan bakımından camilerin neredeyse tamamı kuzey-güney doğrultuda dikdörtgen planlı ve ahşap tavanlıdır. Az sayıdaki camide kare plan uygulanmış; sadece bir camide ise kubbe kullanılmıştır. Diğer yapılar büyük oranda günümüze ulaşmadığı için sağlıklı bir mimari değerlendirme yapılamamıştır. Ancak camilerden hareketle diğer yapılarında oldukça benzer bir kuruluşa ve planlamaya sahip olduğunu düşünebiliriz.

Boyabat'taki yapılar süsleme programı bakımında oldukça sade, işlev ön planda tutulmuş binalardır. Yapılar, yazarın özellikle belirttiği üzere, bölgenin ekonomik durumunun bir yansıması olarak son derece basit ve sade yapılar olarak karşımıza çıkmaktadır. Bununla birlikte ahşap malzeme kullanımına paralel olarak tavan göbeklerinde süslemeye yer verilmiştir. Bunun yanında ahşap süsleme minber, mihrap, kapı kanatları ve dolap kapaklarında uygulanmıştır. Bununla birlikte az sayıdaki yapının mihrabında alçı süsleme, bir yapıda da taş süsleme görülmektedir.

Hurufat Defterleri Kayıtlarında Adı Geçen Vakıflar, Vakıf Görevlileri, Meslekleri, Ücretleri (375-383) başlıklı bölümde, defterlerden elde edilen vakıfların isimleri, hangi yapılara ait oldukları ve vakıf görevlileriyle birlikte yapılarda görevlendirilen kişilerin aldıkları ücretler ele alınmaktadır. Kayıtlarda toplam 107 vakıf adı geçmektedir. Bu vakıfların görevlilerini meslekleri itibariyle ele aldığımızda dini meslekler, idari meslekler, hizmet meslekleri ve eğitim meslekleri şeklinde bir tablo karşımıza çıkmaktadır. Yapıların büyük çoğunluğunu camiler oluşturduğu için görevlilerin çok büyük bir bölümü de imam, hatip ve müezzinler gibi cami görevlileridir. Diğer meslek grupları ise yine yapı sayısındaki orana paralellik göstermektedir. Vakıf görevlilerinin aldıkları ücretlere baktığımız zaman ortalama günde 1 akçe ve yarım akçe almaktadırlar. Günde bir akçeden yüksek alanların oranı ise oldukça düşüktür. Ücretini para yerine çeltik ve buğday gibi ürünlerle alanlar da mevcuttur. Ayrıca sistemin zaaflarından faydalanarak vakıf müessesini kendi çıkarları doğrultusunda kullananlar kayıtlardan tespit edilmiştir.

Kitabın, Kayıtlarımız Dışında Başka Arşiv Belgelerinde Adı Geçen Köyler (384-388) adlı üçüncü bölümünde incelenen hurufat defterleri dışındaki diğer arşiv belgelerinde adı geçen köyler incelenmektedir. Bu belgelerin büyük çoğunluğunu Başbakanlık Osmanlı Arşivi'nde yer alan, 
arazi kayıtlarının tutulduğu tapu tahrir defterleri oluşturur. Hurufat defterlerinde adı geçen köyler için uygulanan yöntem diğer arşiv belgelerinde geçen köyler için de uygulanmıştır. Ancak bu köylerin büyük bir çoğunluğu ya bugün mevcut değildir ya da yerleri tespit edilememiştir.

Kayıtlarımız Dışında Diğer Arşiv Belgelerinde Adı Geçen Yapılar (389-394) başlıklı dördüncü bölümde hurufat defterleri dışında, Başbakanlık Osmanlı Arşivi ve Vakıflar Genel Müdürlüğü Arşivi'ndeki belgelerde Boyabat'ta adı geçen yapılar listelenmektedir. Ancak arşiv belgelerinde geçen yapıların nerede olduğu tam olarak belirtilmediği için büyük çoğunluğunun yer tespiti yapılamamıştır. Tespit edilen yapılar ise günümüze ulaşamamıştır.

Sonuç (395-397) bölümünde çalışmadan elde edilen bilgilerin genel bir yorumlaması yapılmaktadır. Bölgenin coğrafi koşulları, bitki örtüsü ve halkın ekonomik durumuna paralel olarak Boyabat'taki yapıların genellikle küçük ölçekli ve basit mimari kuruluşlara sahip olduklarını söyleyebiliriz. Kitabın sonuç paragrafı Boyabat'taki Türk Eserlerinin genel özelliklerini ve Türk Mimarisi içerisindeki yerini özetlemeye yetmiştir: "Sebebi ne olursa olsun bu sade, basit ve yalın mimari, Yunus Emre'nin Türkçesini çağrıştırıyor. Seyyahların Altaylardan Istanbul'dakilere kadar Türkler için bir övgü olarak yazdıkları basit ve sade hayat tarzının ifadesi olan bu mimariden çağdaş mimarimizin de alacağı çok ders olduğu açıktır." (397)

Yararlanılan Kaynaklar (398-417) üç kategoride verilmiştir. Başbakanlık Osmanlı Arşivleri Genel Müdürlüğü Arşivi (398-409) adlı bölümde söz konusu arşivden alınan bütün belgeler gömlek numarasına göre sıralanmaktadır. Ayrıca belgelerin özetleri de yine burada okuyucuya sunulmaktadır. Vakıflar Genel Müdürlüğü Arşivi (410) bölümünde de bu arşivden temin edilen belgeler ve numaraları verilmektedir. Son olarak Yayınlar (411-417) bölümünde kitapta kullanılan bütün yayınlar yazar soyadlarına göre alfabetik olarak sıralanmaktadır.

Son olarak Ekler (418-517) bölümünde ise yapılar ve köy listeleri, yer adları, vakıflar ve daha birçok bilgi tablo halinde sunulmaktadır. Ayrıca Boyabat kazasında adı geçen yapılardan mevcut olanların ve zaviyelerin yerleri iki ayrı harita üzerinde gösterilmektedir. Hurufat Defterinden bazı sayfalarından örnekler de yine ekler bölümünde yer almaktadır.

Kitap, arşiv belgelerine dayanmasının yanı sıra arazi çalışması da içermesi bakımından oldukça önemlidir. Hurufat Defterlerinde tespit edilen yapıların yerinde görülüp planlarının çıkarılması, fotoğraflarının çekilmesi ve mimari tanımlarının yapılmış olması son derece önemlidir. Sonuç olarak, özellikle son dönemlerde sanat tarihi araştırmalarının tıkandığı ve konu sıkıntısı çekildiği yönündeki iddiaları ortadan kaldıracak nitelikte bir çalışma olduğunu söyleyebiliriz. 